\title{
VARIAÇÕES GRANULOMÉTRICAS E MINERAIS PESADOS DAS PRAIAS DO NORTE DO ESTADO DO RIO DE JANEIRO, SE, BRASIL: CONDIÇÕES DE DISTRIBUIÇÃO E DEPOSIÇÃO DOS SEDIMENTOS
}

\author{
GRAIN SIZE AND HEAVY MINERALS OF NORTHERN RIO DE JANEIRO STATE BEACHES (SE \\ BRAZIL): SEDIMENT DISTRIBUTION AND DEPOSITION CONDITIONS
}

\section{Sarah Siqueira da Cruz Guimarães SOUSA ${ }^{1}$, João Wagner de Alencar CASTRO² \& Eliane GUEDES $^{3}$}

(1) Programa de Pós-Graduação em Geologia. Universidade Federal do Rio de Janeiro. Endereço eletrônico: sarahscgs@ gmail.com

(2) Departamento de Geologia e Paleontologia. Museu Nacional. Universidade Federal do Rio de Janeiro.

Endereço eletrônico: castro@mn.ufrj.br

(3) Departamento de Geologia e Paleontologia. Museu Nacional. Universidade Federal do Rio de Janeiro. Endereço eletrônico: eguedes@mn.ufrj.br

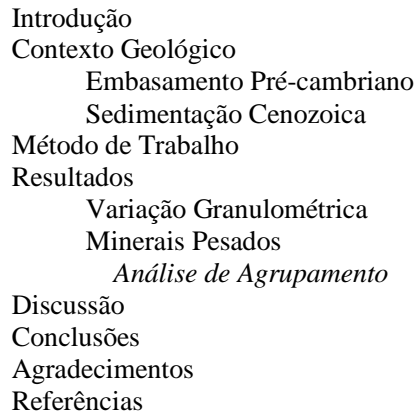

\begin{abstract}
RESUMO - Os depósitos litorâneos de minerais pesados têm sua gênese associada aos processos de intemperismo, erosão, transporte e deposição de sedimentos. Ao serem depositados pelos rios nas regiões costeiras, os sedimentos interagem com ondas e correntes de deriva litorânea, em associação com as variações do nível relativo do mar. Este trabalho tem como objetivo caracterizar os sedimentos de praia localizados entre as desembocaduras dos rios Itabapoana e Paraíba do sul, com enfoque na distribuição granulométrica e ocorrência de minerais pesados. Foram coletadas amostras de sedimentos nos ambientes de ante-praia, praia e póspraia de dez pontos distribuídos ao longo do litoral. As amostras passaram por análises granulométricas e o conteúdo de minerais pesados foi identificado e quantificado. Os sedimentos são moderadamente selecionados, com predomínio de areia média nos pontos mais próximos às desembocaduras dos rios e areia fina e muito fina no restante dos pontos. Os minerais pesados mais abundantes são: ilmenita, limonita, anfibólio e apatita. Os grãos apresentam-se, de modo geral, subangulosos e angulosos, bem preservados, indicando transporte fluvial de curta distância. Como as praias da região são de baixa a média energia, as ondas exercem pouca influência no retrabalhamento dos grãos, possibilitando que os grãos apresentem características fluviais.
\end{abstract}

Palavras-chave: Variação Granulométrica; Sedimentos de Praia; Transporte Sedimentar.

\begin{abstract}
Coastal heavy mineral deposits have their genesis associated with weathering processes, erosion, transport and deposition of sediments. The transport and deposition processes involving rivers, waves and longshore currents, in association with sea-level fluctuations. This paper aims to characterize the beach sediments located between the mouths of Itabapoana and Paraíba do Sul rivers, focusing on grain size distribution and heavy minerals occurrence. Sediment samples were collected on foreshore, shoreface and backshore in ten points distributed along the coast. Grain size analyses were made and the content of heavy minerals has been identified and quantified. The sands are moderately selected, with a predominance of medium sand on beaches near of the river mouths and fine sand and very fine on the other beaches. The most abundant heavy minerals are ilmenite, limonite, amphibole and apatite. The grains are, generally, low-rounded, well preserved, indicating short transport. As the beaches are low to medium energy, the grains reworking by waves are not expressive, allowing fluvial characteristics on the grains.
\end{abstract}

Keywords: Grain Size Distribution; Beach Sediments; Sediment Transport.

\section{INTRODUÇÃO}

Os depósitos de minerais pesados originamse quando as rochas da superfície da Terra são submetidas à ação do intemperismo, que as altera a partir de desagregação física e decomposição química, liberando seus constituintes minerais ao transporte pelos agentes superficiais, como rios, ventos, águas pluviais, gelo e ação da gravidade. Esses sedimentos podem ser depositados in situ, gerando solos residuais, serem transportados e depositados nos rios, gerando depósitos de aluviões, ou ainda, serem transportados pelas descargas fluviais até a desembocadura dos rios. Quando isso ocorre, os sedimentos interagem com ondas e correntes e são distribuídos e depositados na plataforma continental ou nas praias, formando os depósitos litorâneos (Silva, 2001; Pereira et al., 
2005). O processo de deposição no litoral envolve principalmente a ação de ondas e correntes de deriva litorânea, em íntima associação com as variações do nível relativo do mar. Estas modificações do nível marinho permitem a acumulação de minerais pesados no litoral e também podem estar associadas a depósitos fluviais, que recobriam grande parte da plataforma continental, exposta durante fases de nível do mar baixo, posteriormente afogadas pela transgressão marinha que se iniciou no final do Pleistoceno e início do Holoceno (Silva, 2001).

Os minerais pesados em sedimentos arenosos são frequentemente utilizados como indicadores para determinar a proveniência e processos de distribuição (Cascalho et al, 2006; Morton \& Hallsworth, 1994; Morton \& Hallsworth, 1999). Constituem excelentes arquivos que gravam e preservam as assinaturas dos eventos geológicos do passado desde a sua origem até o ambiente deposicional atual (Mange \& Wright, 2007). Um dos principais pontos da análise de minerais pesados é a determinação de uma grande variedade de espécies minerais encontrada em sedimentos, assim como a sua distribuição granulométrica ao longo do arco de praia e os fatores que controlam esta distribuição. Muitos destes minerais têm paragêneses restritas e podem fornecer informações sobre a sua procedência e as rochas-fonte envolvidas.

A área de estudo, localizada na zona costeira do norte fluminense entre as desembocaduras dos rios Paraíba do Sul e Itabapoana, se mostra com grande potencial para acumulação de minerais detríticos pesados (Silva, 2001). Em depósitos de paleopraia na mesma região, a ocorrência de minerais detríticos com valor econômico, como por exemplo, monazita, rutilo, zircão e ilmenita foi explotada com sucesso desde a década de 1940 pela Sociedade Comercial de Minérios Ltda (Sulba) e mais recentemente pelas Indústrias Nucleares do Brasil (INB), para obtenção de terras raras (Rosental, 2008).

Para a mesma região alvo deste estudo, a pesquisa realizada por Gonçalves (2004) identificou espécies e percentuais no conteúdo de minerais pesados, permitindo a correlação com possíveis áreas-fonte. Porém dados relativos à distribuição granulométrica e concentração destes minerais de valor econômico ao longo do litoral norte do Estado do Rio de Janeiro são escassos, ainda mais os que retratam o envolvimento de sedimentos recentes e a dinâmica de deposição atual. Este trabalho tem como objetivo caracterizar os sedimentos de praia localizados entre as desembocaduras dos rios Itabapoana e Paraíba do sul com enfoque na distribuição granulométrica e ocorrência de minerais pesados como forma de contribuir ao entendimento dos processos deposicionais de minerais pesados em praias. Informações sobre as possíveis fontes envolvidas no processo também serão abordadas.

\section{CONTEXTO GEOLÓGICO.}

A geologia da área de estudo é dividida em dois conjuntos principais: o embasamento pré-cambriano e a sedimentação cenozoica. Esses dois conjuntos originaram-se por eventos distintos. $\mathrm{O}$ primeiro teve sua gênese relacionada ao desenvolvimento da Província Tectônica Mantiqueira (Almeida et al., 1981) e o segundo, aos eventos tectônicos cenozóicos, inseridos no contexto do Rift Continental do Sudeste do Brasil (Riccomini et al., 2004) e também pelas variações do nível relativo do mar durante o Holoceno (Castro et al., 2014). São registradas, também, rochas vulcânicas alcalinas, resultantes da reativação das zonas de cisalhamento ao longo do Orógeno Ribeira (Thomaz Filho \& Rodrigues, 1999).

\section{Embasamento pré-cambriano}

O embasamento da área é caracterizado pelo segmento central do Orógeno Ribeira, que se encontra dividido em quatro compartimentos tectônicos: Ocidental, Paraíba do Sul-Embu, Oriental e Cabo Frio, englobando o Estado do Rio de Janeiro e sul do Estado do Espírito Santo (Heilbron et al., 2008) (Figura 1). O Terreno Ocidental é constituído pelas rochas do embasamento dos complexos Mantiqueira e Juíz de Fora, representados por ortognaisses, anfibolitos e ortogranulitos de composições variadas. A sequência sedimentar deformada do Terreno Ocidental é representada por anfibolitos, paragnaisses, xistos e quartzitos. Os terrenos Paraíba do Sul e Embu são separados por uma zona de cisalhamento dextral. O 
Terreno Paraíba do Sul caracteriza-se por ortogranulitos do Complexo Quirino e uma sequência metassedimentar siliciclástica com lentes de mármores dolomíticos e rochas calcissilicáticas. $\mathrm{O}$ Terreno Embu é caracterizado por um embasamento ortognáissico e uma associação metassedimentar do Complexo Embu, constituído por gnaisses, xistos, quartzitos, rochas calcissilicáticas e anfibolitos. O Terreno Oriental é subdividido em três domínios estruturais: Cambuci, Costeiro e Italva. No Domínio Cambuci ocorrem gnaisses migmatíticos intensamente deformados com lentes de olivina-mármores, rochas calcissili- cáticas e granulitos. O Domínio Costeiro é composto por ortognaisses e paragnaisses pelíticos de alto grau metamórfico. O Domínio Italva compreende uma sucessão metassedimentar rica em plataformas carbonáticas, constituída por gnaisses, mármores calcíticos, anfibolitos e anfibólioxistos (Heilbron et al., 2004; 2008; Tupinambá et al., 2007). O Terreno Cabo Frio é constituído por ortognaisses de composição tonalítica a granítica com enclaves dioríticos e abundantes lentes de anfibolitos e também por rochas metassedimentares de alto grau (Schmitt et al., 2004).

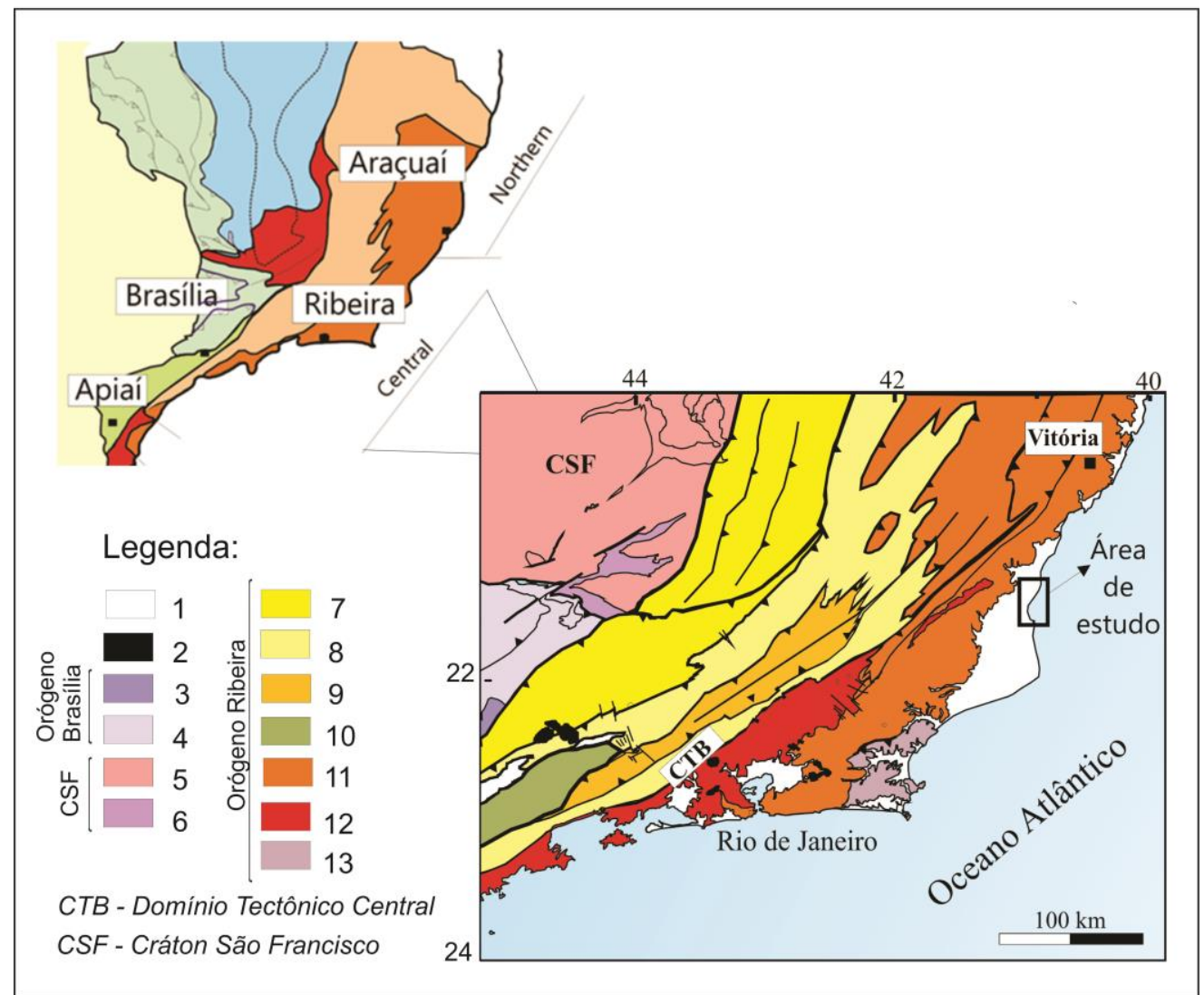

Figura 1. Mapa tectônico do segmento central do Orógeno Ribeira no contexto da Província Tectônica Mantiqueira. O retângulo em preto indica a área de estudo. 1: Riftes Cenozoicos; 2: Rochas Alcalinas do Cretáceo e Neógeno; 3:

Nappes Inferiores; 4: Nappes Superiores; 5: Embasamento do Cráton São Francisco e Domínio Autóctone; 6:

Metassedimentos do Domínio Autóctone; 7: Domínio Andrelândia; 8: Domínio Juiz de Fora do Terreno Ocidental; 9 : Terreno Paraíba do Sul; 10: Terreno Embu; 11: Terreno Oriental; 12: Arco Magmático Rio Negro; 13: Terreno Cabo Frio. Modificado de Heilbron et al. (2004).

\section{Sedimentação cenozoica}

A sedimentação cenozoica é representada pela Formação Barreiras e pelos depósitos quaternários (Figura 2). A ocorrência de maior expressividade da Formação Barreiras no Estado do Rio de Janeiro é registrada ao norte da foz do rio Paraíba do Sul (Martin et al., 1997; Silva e Cunha, 2001). Nesta região, os afloramentos projetam-se até o ambiente de praia, que por sua vez, são atingidos por ondas e correntes de deriva litorânea. Morais et al. (2006) classificaram a Formação Barreiras dessa região como arenitos intercalados com lamitos e presença inexpressiva de níveis de cascalho. A coloração dos depósitos é brancaacinzentada, com forte mosqueamento vermelho-arroxeado, com a presença de níveis limoníticos delimitando camadas e crostas 
ferruginosas bem desenvolvidas. Esses sedimentos são de origem continental e seu ambiente deposicional é atribuído a rios entrelaçados (Morais et al., 2006; Morais, 2007).

Os depósitos quaternários caracterizam-se por sedimentos marinhos e continentais de idade pleistocênica e holocênica. Os depósitos pleistocênicos representam terraços constituídos por sedimentos arenosos de coloração esbranquiçada na superfície e acastanhados em profundidade. Sedimentos de coloração escura geralmente são atribuídos à presença de matéria orgânica. As porções mais internas das planícies costeiras podem variar de 8,0 a 10 metros de altitude, diminuindo em direção ao mar (Martin et al., 1997). Os vales são ocupados por sistema de drenagem de grande porte representados pelos rios Paraíba do Sul e Itabapoana. Conforme Castro et al. (2009), os terraços holocênicos caracterizam-se por terras baixas e alagadas, datadas em aproximadamente 5.100 anos A.P. Em geral, os sedimentos são constituídos por material síltico e areno-argiloso, rico em matéria orgânica. As praias são dominadas principalmente por ondas do quadrante nordeste com predominância de corrente de deriva litorânea de norte para sul, denotando de modo geral ambiente de baixa à média energia.

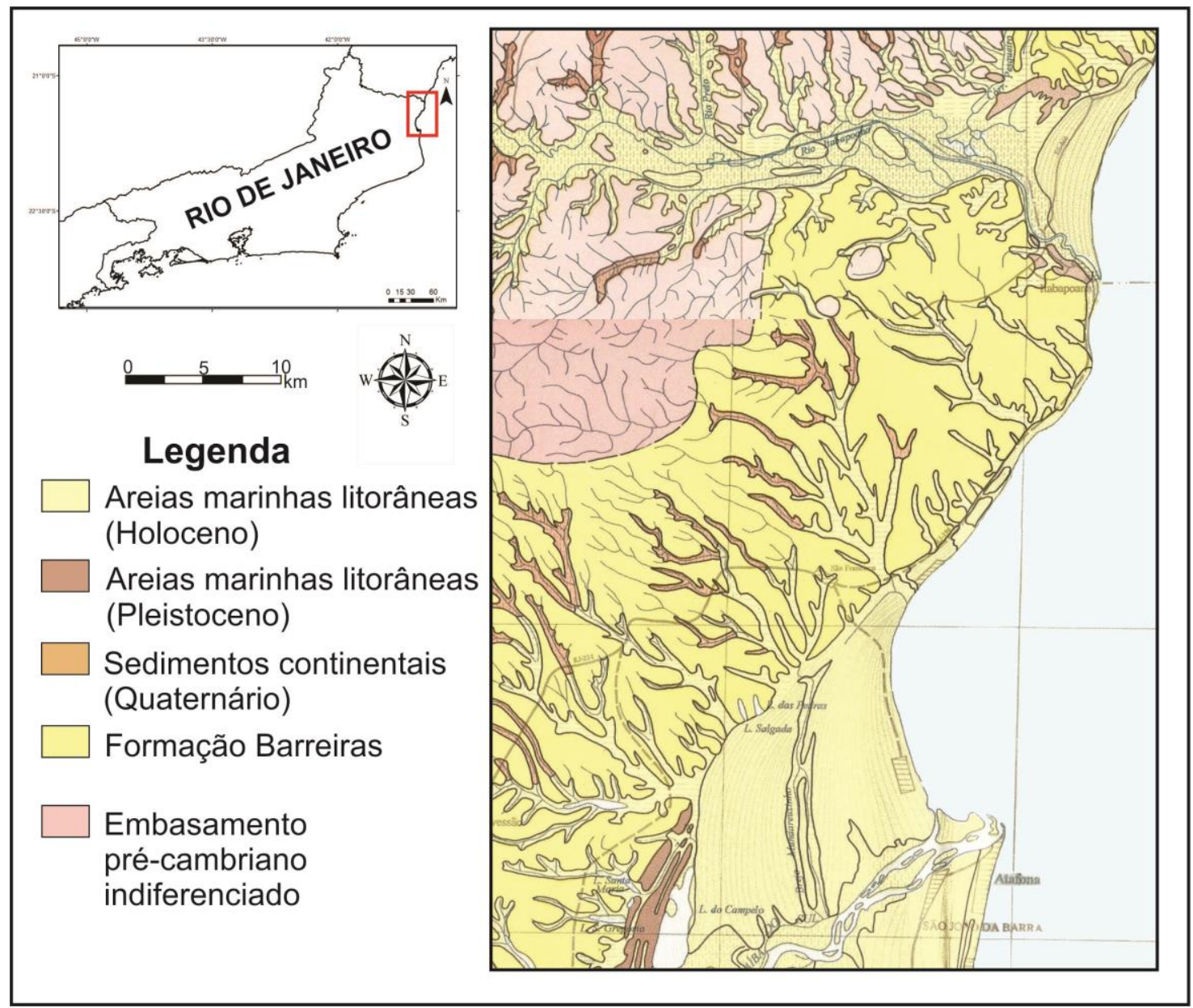

Figura 2 - Mapa geológico do Quaternário costeiro das partes norte do Estado do Rio de Janeiro e sul do Estado do Espírito Santo. Modificado de Martin et al. (1997).

\section{MÉTODO DE TRABALHO}

A metodologia envolveu o trabalho de campo e a preparação laboratorial. Durante a etapa de campo foram coletadas amostras ao longo de $35 \mathrm{~km}$ (Figura 3) de um trecho litorâneo limitado por duas grandes desembocaduras de rios, ao sul pelo rio Paraíba do Sul e ao norte pelo rio Itabapoana (Figura
3). Os pontos amostrais distam entre si em torno de $3 \mathrm{~km}$, totalizando 10 pontos. Em cada um desses pontos foram coletadas amostras de aproximadamente $2 \mathrm{~kg}$ de sedimento dos ambientes de ante-praia, praia e pós-praia. Com isso, buscou-se uma representatividade dos sedimentos ao longo do litoral estudado. 


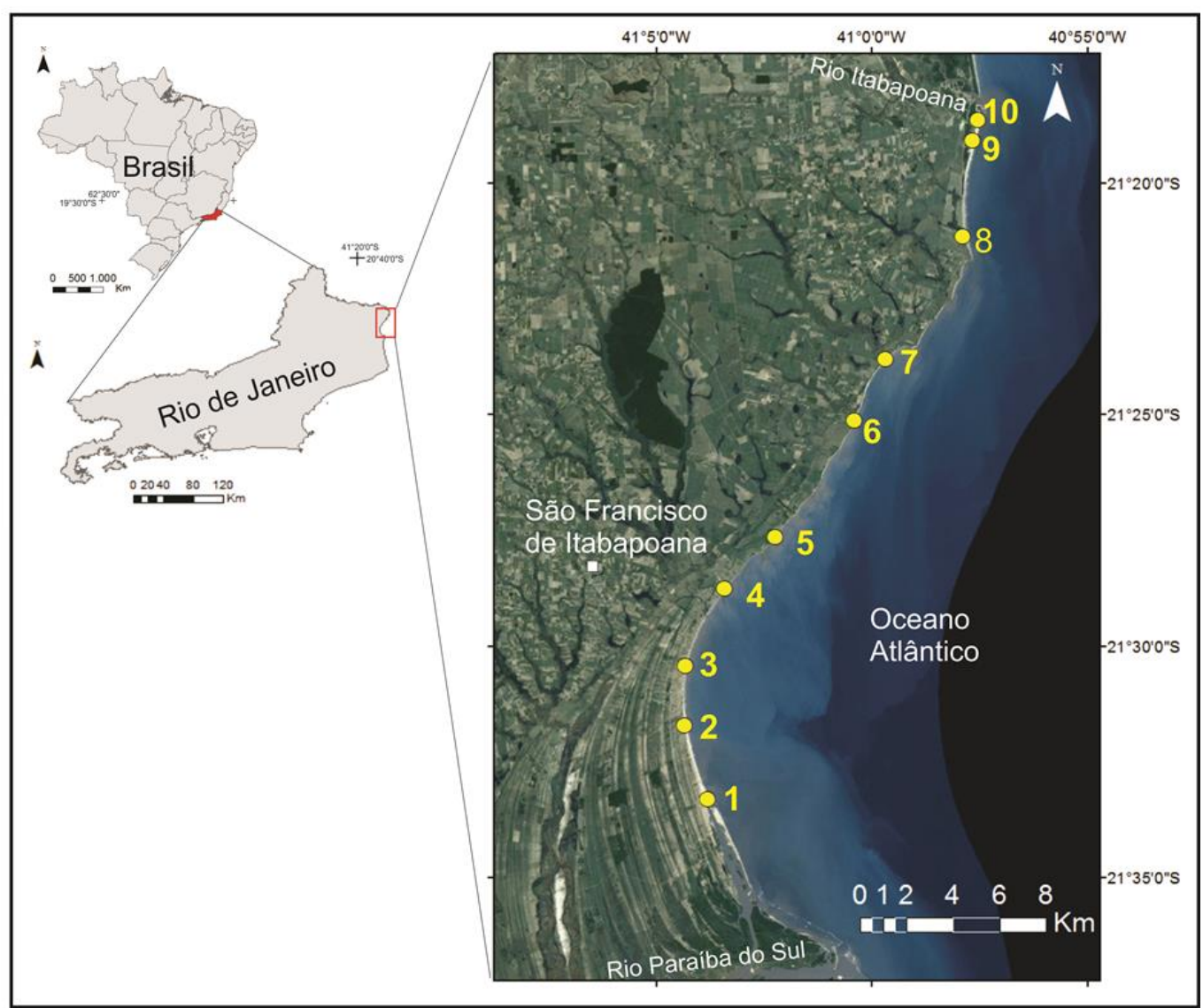

Figura 3. Pontos de coletas de amostras no litoral norte fluminense, Rio de Janeiro, sudeste brasileiro. Os pontos em amarelo indicam os pontos de coleta. 1: Gargaú I; 2: Gargaú II; 3: Santa Clara; 4: Guaxindiba; 5: Manguinhos; 6:

Fazenda Buena; 7: Tatagiba; 8: Ponta do Retiro; 9: Barra de Itabapoana I; 10: Barra de Itabapoana II.

Em laboratório, as amostras foram quarteadas e $200 \mathrm{~g}$ de material foram utilizados para a análise granulométrica conforme adaptação da metodologia proposta por Suguio (1973). O peneiramento foi realizado por um jogo de peneiras com intervalos de 1,0 $\boldsymbol{\varphi}$ na escala de Wentworth - Krumbein. Cada uma das frações foi pesada e os dados foram tratados no programa Sedigraph.

Para análise dos minerais pesados foi utilizada a metodologia adaptada de Mange e Maurer (1992) e envolveu a concentração dos minerais pesados e seu processamento (Figura 4). Inicialmente, $500 \mathrm{~g}$ de material foram separados e concentrados por bateamento e os produtos finais submetidos à dissolução do conteúdo de carbonatos por imersão em ácido acético a $10 \%$. Posteriormente, foi realizada a separação densimétrica por imersão em líquido denso (bromofórmio $\mathrm{d}=$ $2,89 \mathrm{~kg} / \mathrm{cm} 3$ ) para a separação dos minerais leves, como o quartzo e feldspato. Durante este processo, todo o material foi recuperado e pesado para o cálculo das porcentagens de minerais pesados em relação aos leves. Para a separação magnética foi utilizado o ímã de ferrite, para a retirada de material ferromagnético e o separador magnético isodinâmico Frantz, com as correntes de 0,3 $\mathrm{A}, 0,5 \mathrm{~A}, 0,8 \mathrm{~A}$ e $1,5 \mathrm{~A}$ para a separação das diferentes fases de minerais paramagnéticos e diamagnéticos.

As frações obtidas por meio do separador Frantz foram analisadas em estereomicroscópio para a identificação e caracterização dos minerais pesados, de acordo com suas características físicas, tais como cor, brilho, clivagem e forma.

A quantificação porcentual dos minerais pesados foi realizada em estereomicroscópio por estimativa visual, de acordo com Pereira et al., (2005). Os resultados obtidos das concentrações de cada espécie mineral das amostras foram manipulados estatisticamente por meio da análise de agrupamento (cluster analysis), com coeficiente de distância euclidiana como medida de similaridade, segundo a metodologia proposta por Parks (1966) para discriminação de assembleias mineralógicas. 


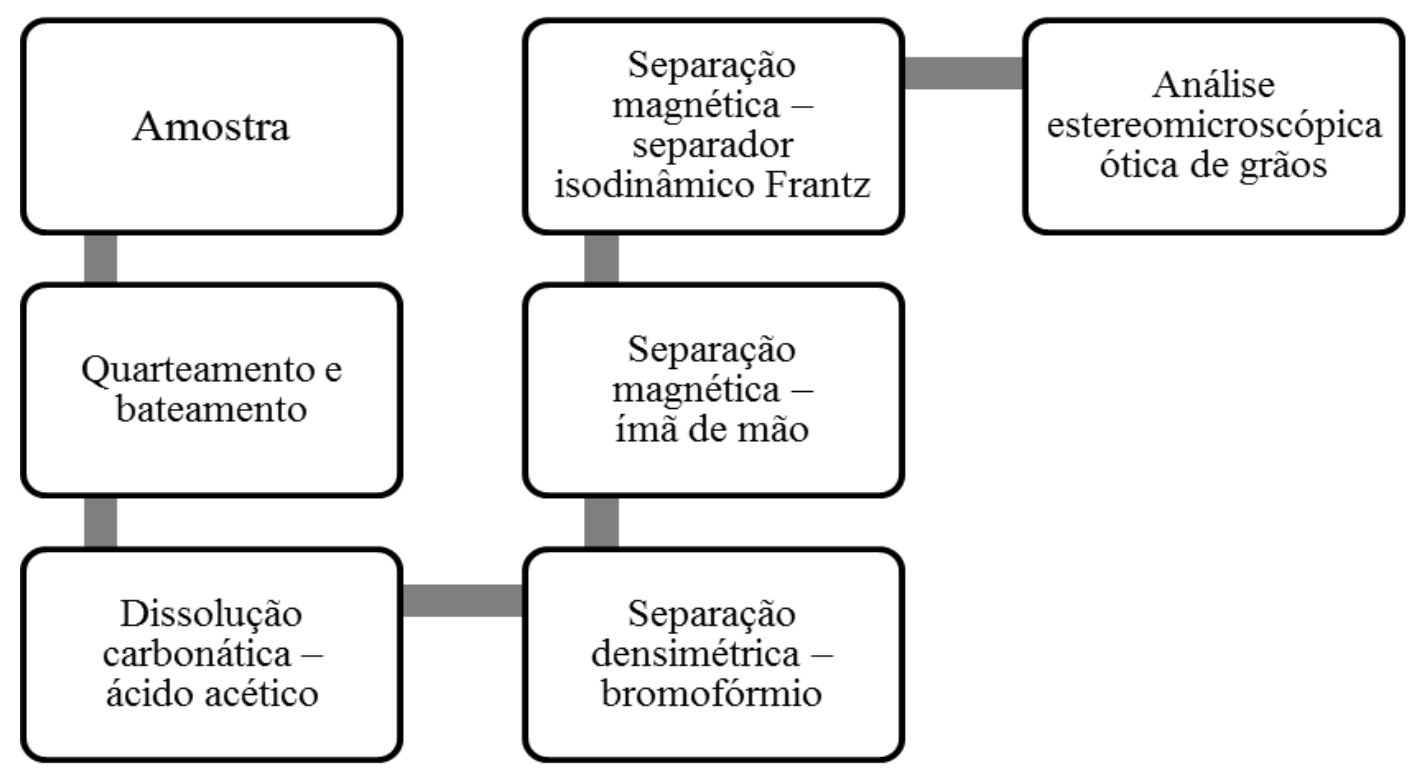

Figura 4 - Fluxograma mostrando a preparação da amostra para a análise estereomicroscópica de grãos de minerais pesados.

\section{RESULTADOS}

\section{Variação Granulométrica}

As informações das coletas realizadas em campo são apresentadas na tabela 1 . O estágio morfodinâmico de uma praia pode ser relacionado com a energia das ondas e declive da plataforma, assim, o estado dissipativo denota uma praia com uma menor energia nos seus processos, quando comparado ao estágio intermediário e refletivo (USACE, 1995).

Tabela 1 - Denominações dos pontos de coleta, localização em coordenadas UTM, declividade da face da praia e estágio morfodinâmico observado.

\begin{tabular}{|c|c|c|c|c|}
\hline Ponto & Local & $\begin{array}{c}\text { Coordenadas } \\
\text { UTM }\end{array}$ & $\begin{array}{c}\text { Declividade da } \\
\text { praia }\end{array}$ & $\begin{array}{c}\text { Estágio } \\
\text { morfodinâmico }\end{array}$ \\
\hline $\mathbf{1}$ & Gargaú I & $\begin{array}{c}24 \mathrm{~K}-286253 \mathrm{E} / \\
7614996 \mathrm{~N}\end{array}$ & $12^{\circ}$ & Intermediário \\
\hline $\mathbf{2}$ & Gargaú II & $\begin{array}{c}24 \mathrm{~K}-285314 \mathrm{E} / \\
7617943 \mathrm{~N}\end{array}$ & $12^{\circ}$ & Intermediário \\
\hline $\mathbf{3}$ & Santa Clara & $\begin{array}{c}24 \mathrm{~K}-285289 \mathrm{E} / \\
7620330 \mathrm{~N}\end{array}$ & $4^{\circ}$ & Dissipativo \\
\hline $\mathbf{4}$ & Guaxindiba & $\begin{array}{c}24 \mathrm{~K}-286820 \mathrm{E} / \\
7623426 \mathrm{~N}\end{array}$ & $5^{\circ}$ & Dissipativo \\
\hline $\mathbf{5}$ & Manguinhos & $\begin{array}{c}24 \mathrm{~K}-288846 \mathrm{E} / \\
7625502 \mathrm{~N}\end{array}$ & $6^{\circ}$ & Dissipativo \\
\hline $\mathbf{6}$ & Fazenda Buena & $\begin{array}{c}24 \mathrm{~K}-291958 \mathrm{E} / \\
7630176 \mathrm{~N}\end{array}$ & $2^{\circ}$ & Dissipativo \\
\hline $\mathbf{7}$ & Tatagiba & $\begin{array}{c}24 \mathrm{~K}-293173 \mathrm{E} / \\
763266 \mathrm{~N}\end{array}$ & $3^{\circ}$ & Dissipativo \\
\hline $\mathbf{8}$ & Ponta do Retiro & $\begin{array}{c}24 \mathrm{~K}-296223 \mathrm{E} / \\
7637570 \mathrm{~N}\end{array}$ & $3^{\circ}$ & Dissipativo \\
\hline $\mathbf{9}$ & Barra de Itabapoana I & $\begin{array}{c}24 \mathrm{~K}-296569 \mathrm{E} / \\
7641411 \mathrm{~N}\end{array}$ & $8^{\circ}$ & Intermediário \\
\hline $\mathbf{1 0}$ & Barra de Itabapoana II & $\begin{array}{c}24 \mathrm{~K}-296761 \mathrm{E} / \\
7642228 \mathrm{~N}\end{array}$ & $5^{\circ}$ & Dissipativo \\
\hline
\end{tabular}

De acordo com os parâmetros granulométricos estatísticos (tabela 2), a maioria dos sedimentos é moderadamente selecionado, com predomínio de areia média nos pontos Gargaú I, Gargaú II, Guaxindiba e Barra de Itabapoana II e areia fina e muito fina no restante dos pontos (Figura 5). 
Tabela 2- Parâmetros estatísticos da análise granulométrica: moda e seleção dos sedimentos. Os itens A, B e C correspondem a ante-praia, praia e pós-praia.

\begin{tabular}{|c|c|c|c|}
\hline & Amostra & Moda & Seleção \\
\hline \multirow{3}{*}{ Gargaú I } & 1A & Areia média & Moderadamente selecionado \\
\hline & 1B & Areia média & Moderadamente selecionado \\
\hline & $1 \mathrm{C}$ & Areia média & Moderadamente bem selecionado \\
\hline \multirow{3}{*}{ Gargaú II } & $2 A$ & Areia média & Moderadamente selecionado \\
\hline & 2B & Areia média & Moderadamente selecionado \\
\hline & 2C & Areia grossa & Moderadamente selecionado \\
\hline \multirow{3}{*}{ Santa Clara } & 3A & Areia fina & Moderadamente selecionado \\
\hline & 3B & Areia muito fina & Moderadamente bem selecionado \\
\hline & $3 C$ & Areia fina & Moderadamente selecionado \\
\hline \multirow{3}{*}{ Guaxindiba } & $4 \mathrm{~A}$ & Silte grosso & Pobremente selecionado \\
\hline & 4B & Areia média & Moderadamente selecionado \\
\hline & 4C & Areia média & Moderadamente selecionado \\
\hline \multirow{3}{*}{ Manguinhos } & $5 A$ & Areia muito fina & Moderadamente bem selecionado \\
\hline & 5B & Areia muito fina & Pobremente selecionado \\
\hline & 5C & Areia média & Pobremente selecionado \\
\hline \multirow{3}{*}{$\begin{array}{c}\text { Fazenda } \\
\text { Buena }\end{array}$} & $6 \mathrm{~A}$ & Areia muito fina & Muito bem selecionado \\
\hline & 6B & Areia muito fina & Moderadamente selecionado \\
\hline & 6C & Areia muito fina & Moderadamente selecionado \\
\hline \multirow{3}{*}{ Tatagiba } & $7 A$ & Areia muito fina & Moderadamente bem selecionado \\
\hline & 7B & Areia muito fina & Moderadamente selecionado \\
\hline & 7C & Areia muito fina & Pobremente selecionado \\
\hline \multirow{3}{*}{$\begin{array}{c}\text { Ponta do } \\
\text { Retiro }\end{array}$} & $8 \mathrm{~A}$ & Areia muito fina & Moderadamente bem selecionado \\
\hline & 8B & Areia fina & Moderadamente bem selecionado \\
\hline & $8 \mathrm{C}$ & Areia muito fina & Moderadamente bem selecionado \\
\hline \multirow{3}{*}{$\begin{array}{c}\text { Barra de } \\
\text { Itabapoana I }\end{array}$} & 9A & Areia média & Moderamente selecionado \\
\hline & 9B & Areia média & Moderadamente selecionado \\
\hline & 9C & Areia média & Moderadamente bem selecionado \\
\hline \multirow{3}{*}{$\begin{array}{c}\text { Barra de } \\
\text { Itabapoana II }\end{array}$} & $10 \mathrm{~A}$ & Areia fina & Moderadamente selecionado \\
\hline & 10B & Areia fina & Moderadamente bem selecionado \\
\hline & $10 \mathrm{C}$ & Areia muito fina & Moderadamente selecionado \\
\hline
\end{tabular}

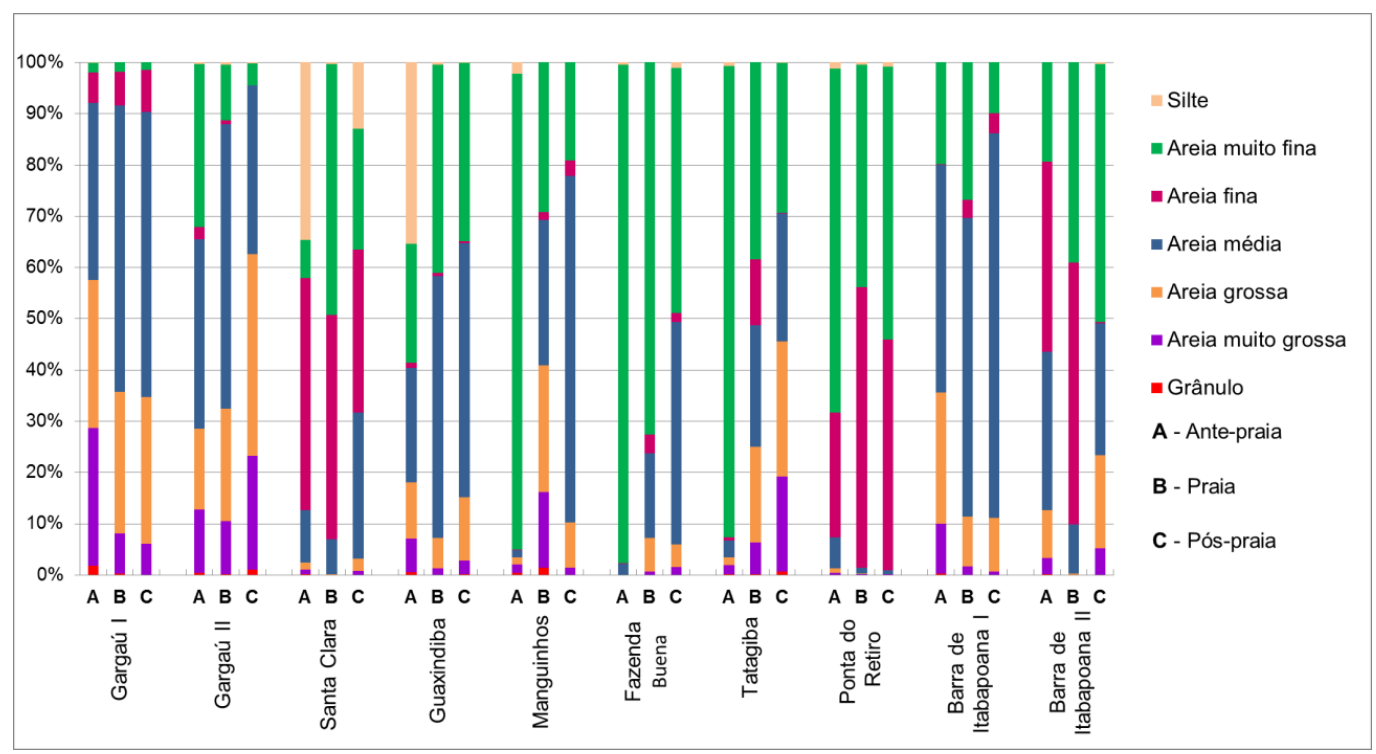

Figura 5 - Distribuição granulométrica dos sedimentos nos ambientes de ante-praia, praia e pós-praia de cada ponto do litoral. 


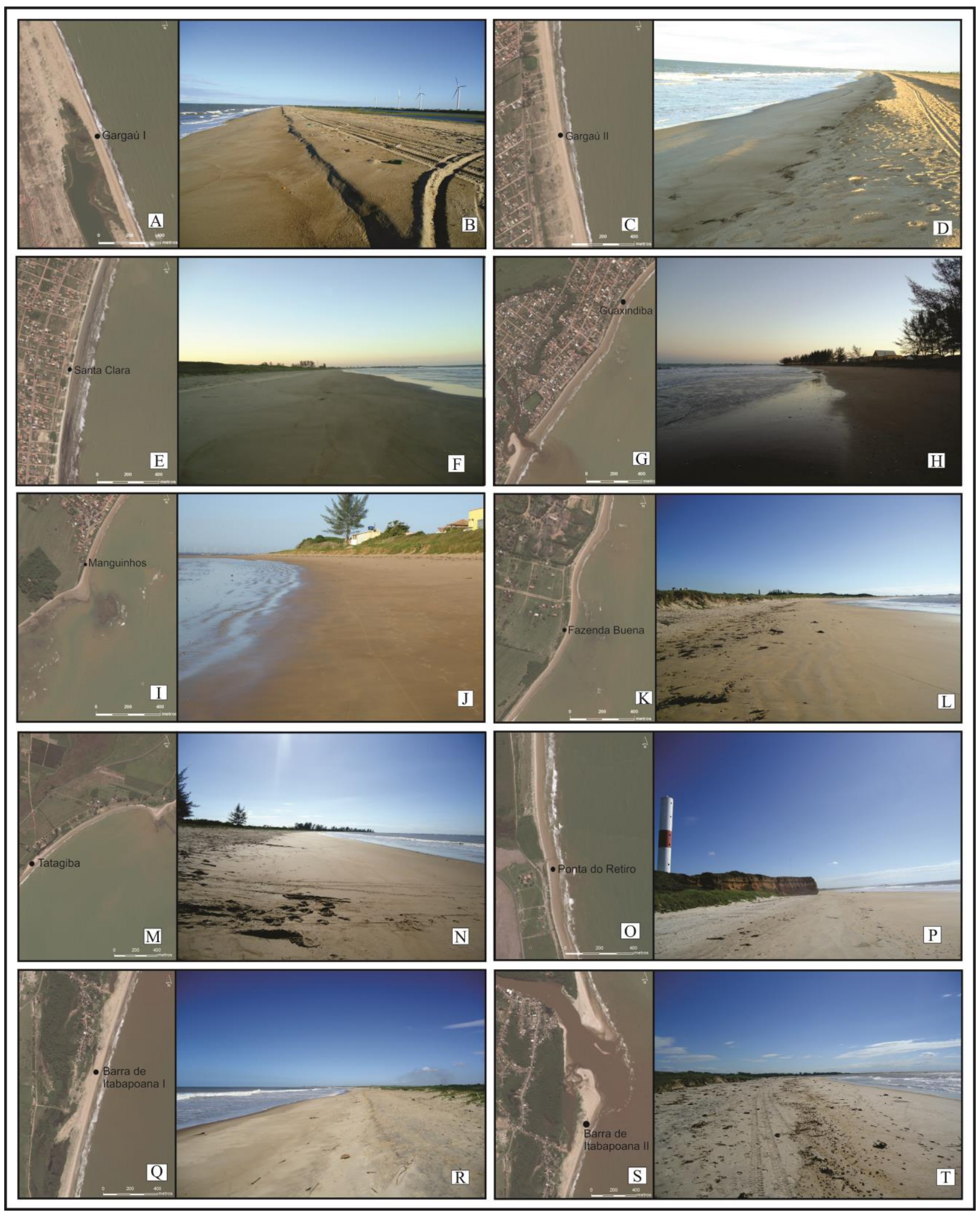

Figura 6- A, C, E, G, I, K, M, O, Q, S: Imagens de satélite (Basemap - Arcgis) com os pontos de coleta e suas respectivas praias representadas pelas fotos: B: Gargaú I; D: Gargaú II; F: Santa Clara; H: Guaxindiba; J: Manguinhos; L: Fazenda Buena; N: Tatagiba; P: Ponta do Retiro; R: Barra de Itabapoana I; T: Barra de Itabapoana II.

Os parâmetros granulométricos estatísticos foram utilizados para a classificação dos sedimentos proposto por Friedman (1961), cujos vértices são representados por assimetria e desvio padrão (seleção) (Figura 7). As amostras da face da praia (B) de todos os pontos plotam no campo de sedimentos fluviais, indicando um inexpressivo retrabalhamento por ondas, o mesmo padrão foi observado pra as amostras de ante-praia e pós-praia. 


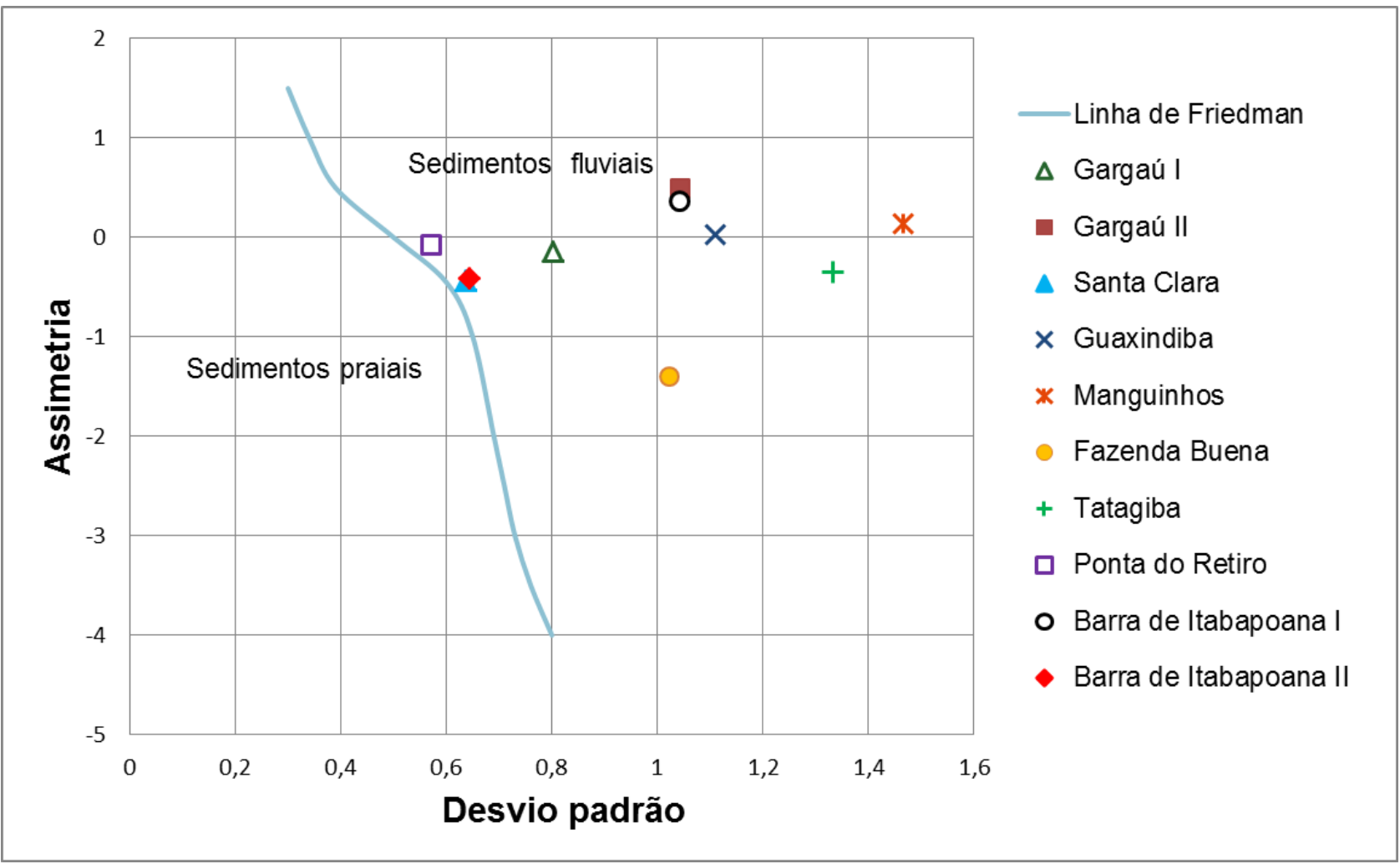

Figura 7 - Assimetria x desvio padrão aplicado para a classificação dos sedimentos fluviais e praiais segundo Friedman (1961).

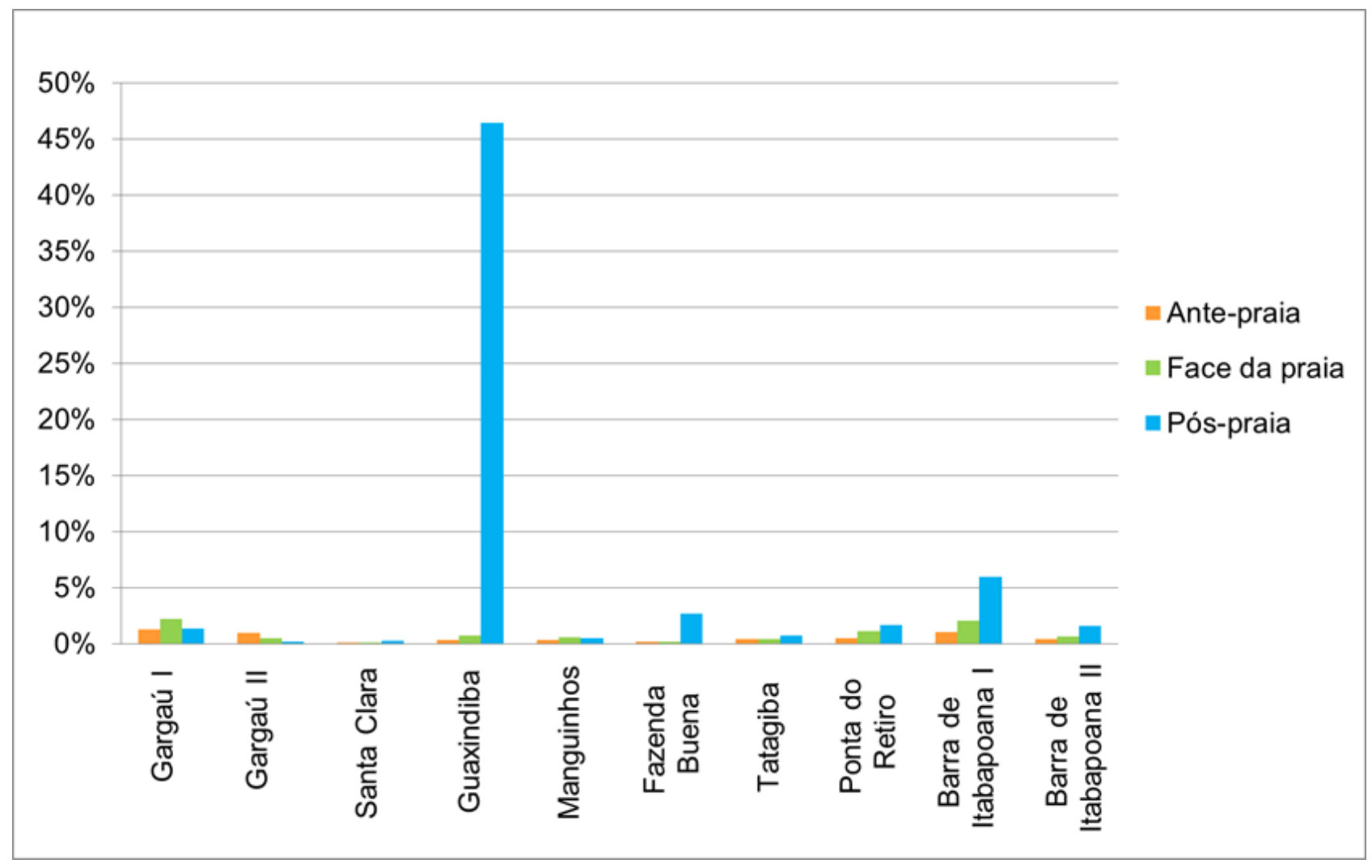

Figura 8 - Porcentagem dos minerais pesados em relação aos leves nos ambientes de ante-praia, praia e pós-praia (C) de cada ponto amostral. 


\section{Minerais pesados}

A concentração de minerais pesados em relação aos leves das praias revela uma alta porcentagem na maioria dos pontos estudados. Destaca-se a alta concentração de minerais pesados no ambiente de pós-praia de Guaxindiba e Barra de Itabapoana I e também a baixa concentração nos ambientes praiais de Santa Clara (Figura 8).

Foram identificados os seguintes minerais: anfibólio, apatita, biotita, cianita, epidoto, espinélio, estaurolita, granada, ilmenita, limonita, monazita, muscovita, piroxênio, rutilo, sillimanita, turmalina e zircão, cujas principais características estão sintetizadas na tabela 3 e na figura 9. Na fração separada pelo ímã de mão foi identificada a magnetita, entretanto, esta não foi quantificada.

A porcentagem dos minerais analisados nos concentrados de pesados revela a alta proporção dos minerais opacos, limonita e ilmenita, variando de $3 \%$ a $85 \%$ das amostras. Entre os minerais transparentes, pode-se destacar a abundância de anfibólio, apatita, zircão, sillimanita, cianita, monazita e granada (Figura 10).

Tabela 3 - Descrição das características dos minerais pesados

\begin{tabular}{|c|c|}
\hline Mineral & Características \\
\hline Anfibólio & $\begin{array}{l}\text { Duas populações características de grãos: verde escuro a preto - apresenta estrias nas faces e seus grãos são } \\
\text { anédricos, subangulosos e fraturados; verde intenso - apresenta-se subédrico, anguloso e pouco fraturado }\end{array}$ \\
\hline Apatita & Grãos incolores de brilho vítreo. A maioria dos gãos é euédrico com prismas alongados. \\
\hline Biotita e muscovita & $\begin{array}{l}\text { Grãos lamelares com clivagem basal perfeita. A biotita encontra-se marrom e em algumas amostras dourada } \\
\text { com brilho esverdeado. A muscovita apresenta-se transparente incolor. }\end{array}$ \\
\hline Cianita & Grãos achatados com clivagem aparente. Apresentam-se incolores e com brilho vítreo. \\
\hline Epidoto & $\begin{array}{c}\text { Grãos com coloração verde amarelada típica, apresentam estrias e fraturamentos e encontram-se } \\
\text { subangulosos }\end{array}$ \\
\hline Espinélio & $\begin{array}{l}\text { Grãos octaédricos perfeitos com vértices arredondados. As cores variam de azul, verde azulado, incolor até } \\
\text { rosa claro. Brilho translúcido }\end{array}$ \\
\hline Estaurolita & $\begin{array}{l}\text { Grãos angulosos, euédricos com prismas alongados. São frequentes inclusões de minerais opacos e } \\
\text { geminações }\end{array}$ \\
\hline Granada & Grãos com colorações rosas claro e alaranjadas. Apresentam-se como fragmentos irregulares e angulosos. \\
\hline Ilmenita & $\begin{array}{l}\text { Grãos tabulares de coloração preta. A maioria dos grãos encontram-se subarredondados. Aparecem alterações } \\
\text { esbranquiçadas, conhecida como leucoxênio, facilitando assim, seu reconhecimento. }\end{array}$ \\
\hline Limonita & $\begin{array}{l}\text { Apresentam-se como grãos arredondados ou agregados de grãos irregulares. As colorações são vermelho, } \\
\text { amarelo ocre e castanho. Alguns grãos têm aspectos ferruginizados }\end{array}$ \\
\hline Monazita & Grãos arredondados e achatados, de coloração amarela intensa. São frequentes formatos ovóides. \\
\hline Piroxênio & Grãos de coloração verde acastanhada e castanha com brilho translúcido. Apresentam-se subarredondados \\
\hline Rutilo & $\begin{array}{l}\text { Grãos de coloração vermelha intensa e preta. Apresenta brilho submetálico com bordas frequentemente } \\
\text { foscas. Caracteriza-se por hábito prismático. }\end{array}$ \\
\hline Sillimanita & Grãos incolores e marrons claro. Encontram-se angulosos com muitas estrias nas faces. \\
\hline Turmalina & $\begin{array}{l}\text { Grãos castanhos euédricos angulosos. Formatos variados, exibindo prismas longos e curtos, trigonais e por } \\
\text { vezes pseudo-hexagonais. Inclusões de minerais opacos são frequentes. }\end{array}$ \\
\hline Zircão & $\begin{array}{l}\text { Duas populações de grãos: incolor com prisma longo e castanho com prismas curtos. Ambos encontram-se } \\
\text { euédricos, com terminações em bipirâmide. Alguns grãos encontram-se subarredondados. }\end{array}$ \\
\hline
\end{tabular}




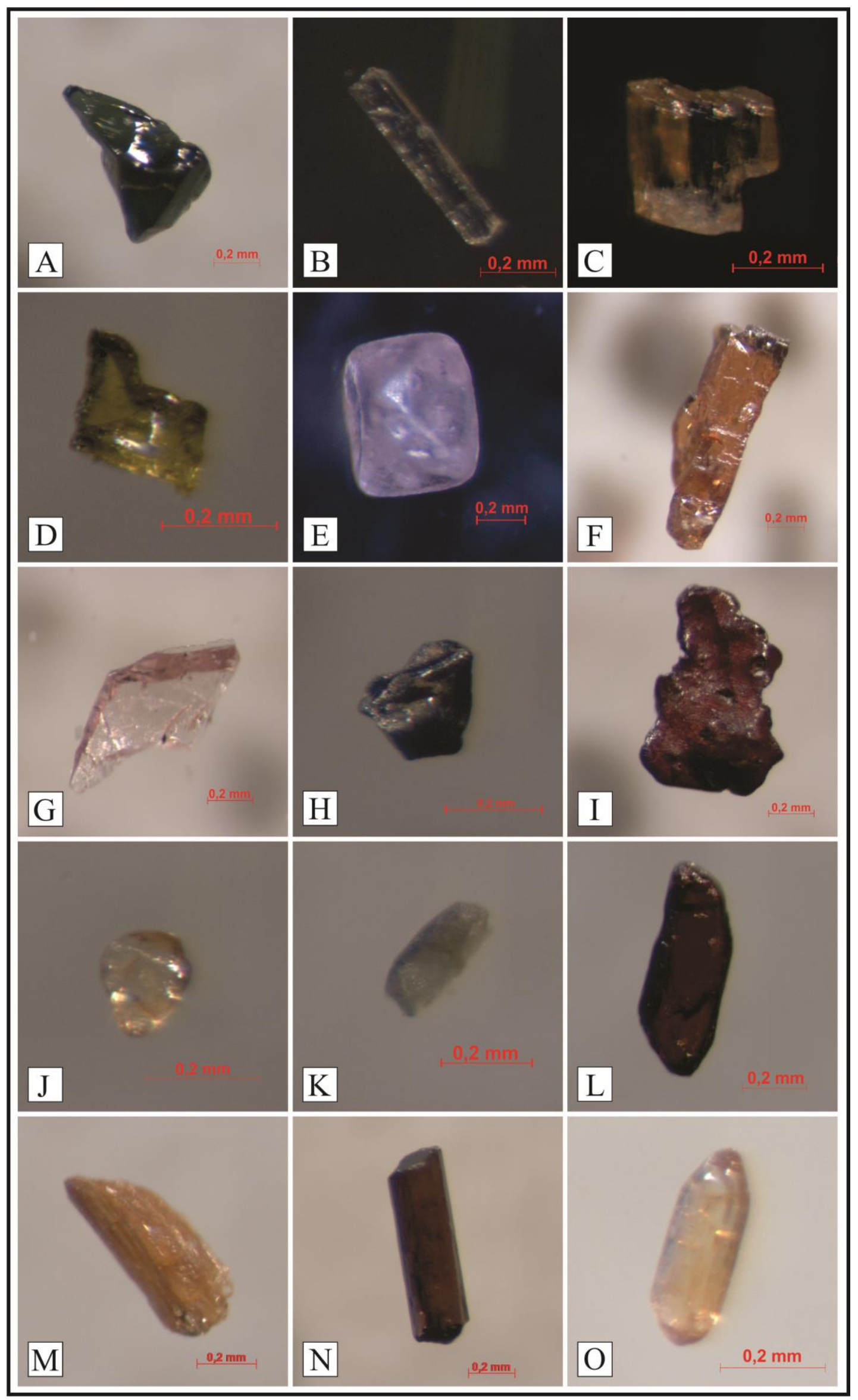

Figura 9 - Fotomomicrografia dos grãos de minerais pesados das praias do norte do Estado do Rio de Janeiro. A: anfibólio; B: apatita; C; cianita; D: epidoto; E: espinélio; F: estaurolita; G: granada; H: ilmenita; I: limonita; J: monazita; K: piroxênio; L: rutilo; M: sillimanita; N: turmalina; O: zircão. 


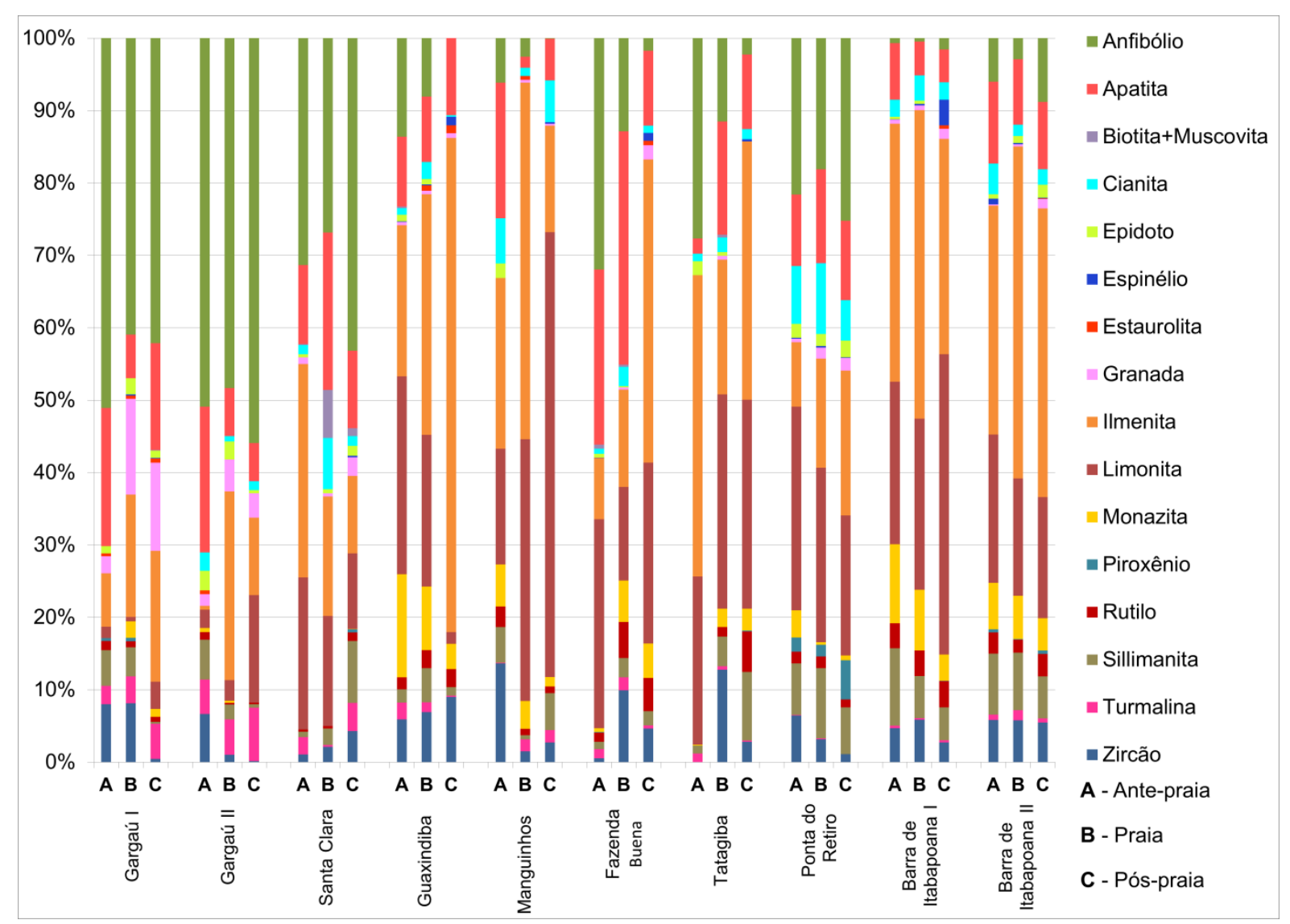

Figura 10 - Porcentagem dos minerais pesados nos ambientes de ante-praia (A), praia (B) e pós-praia (C) de cada ponto amostral.

\section{Análise de agrupamento}

No dendograma gerado a partir da análise de agrupamentos foi possível discriminar três assembleias mineralógicas distintas, com base no grau de similaridade abaixo de quatro (Figura 11):

- Assembleia 1: Compreende as amostras 1B e 2B, Os minerais que caracterizam essa assembleia em ordem decrescente de concentração são anfibólio, ilmenita, granada, apatita, turmalina, zircão e sillimanita;

- Assembleia 2: Formada pelas amostras 3B, 8B, 6B e 7B. Seus minerais característicos são limonita, ilmenita, anfibólio, apatita, zircão, cianita, sillimanita e monazita;

- Assembleia 3: As amostras 4B, 5B, 9B e 10B são caracterizadas por essa assembleia constituída de ilmenita, limonita, apatita, monazita, sillimanita, rutilo e cianita.

\section{DISCUSSÃO}

Com base nos dados granulométricos, apesar de estarem localizados em um ambiente de praia, os sedimentos tem características exclusivamente fluviais. Tal fato pode ser relacionado à área de estudo se encontrar entre duas grandes desembocaduras de rios, como os rios Paraíba do Sul e Itabapoana e ser influenciada por praias de baixa a média energia.

O transporte de sedimentos é promovido pela corrente de deriva litorânea imposta pela ação das ondas de nordeste e sudeste. De acordo com o estado de mar da bacia de Campos (Pinho, 2003), a predominância da direção de ondas que incide no litoral estudado é de nordeste. A deriva litorânea acompanha essa orientação transportando os sedimentos de norte para sul.

As praias de Gargaú II, Guaxindiba e Manguinhos registram um aumento da granulometria em direção à pós-praia. Este aumento pode estar relacionado à ação das ondas de tempestade do quadrante sudeste que remove seletivamente o material mais fino e leve. Este processo sedimentar propicia uma alta concentração de minerais pesados em ambientes costeiros (Komar, 2007), que é evidenciada, principalmente, em Guaxindiba, 


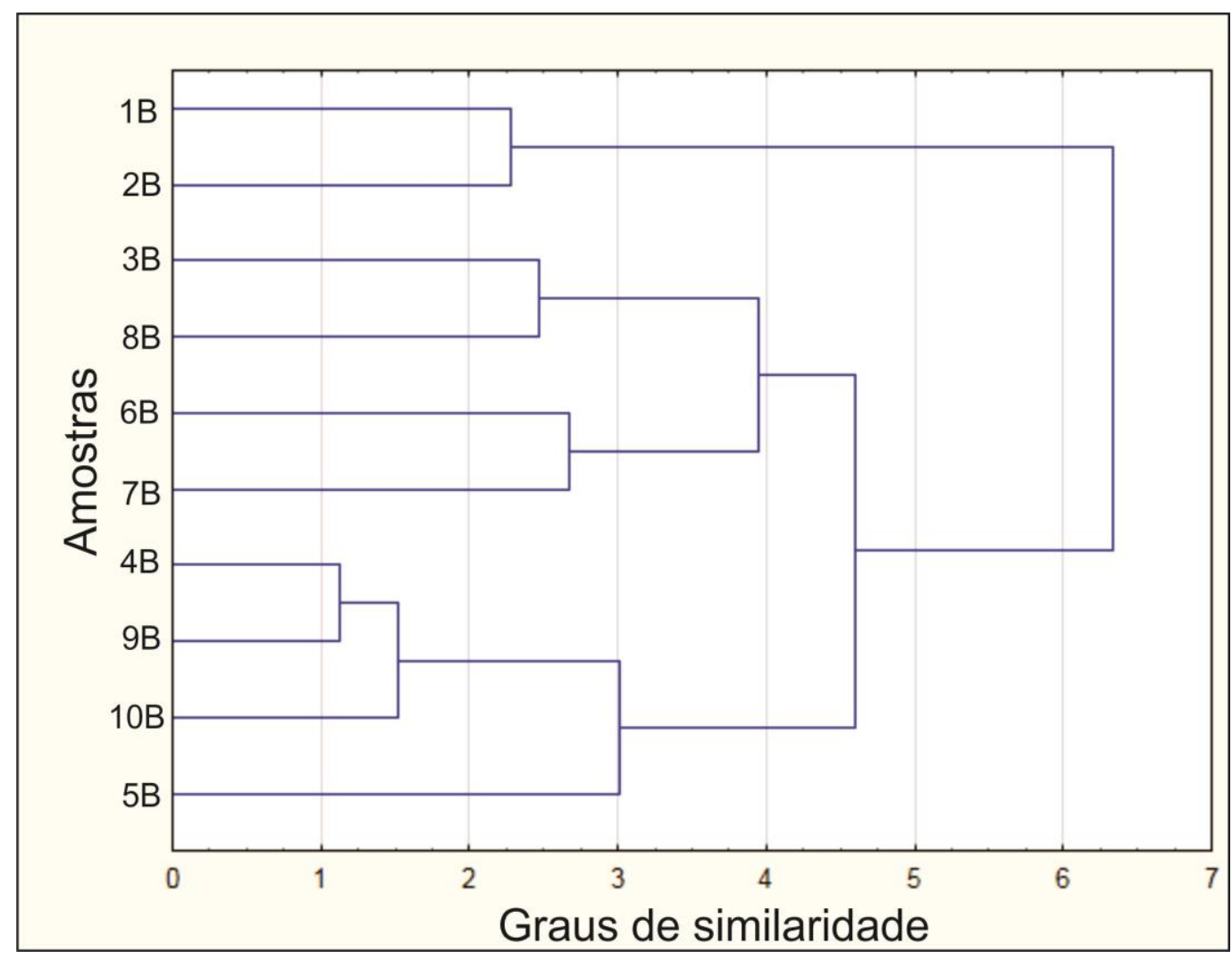

Figura 11 - Dendograma de agrupamento hierárquico dos graus de similaridades entre assembleias de minerais pesados.

Fazenda Buena e Barra de Itabapoana I. A concentração anomalamente alta observada na praia de Guaxindiba pode estar relacionada à descarga fluvial localizada a $1,3 \mathrm{~km}$ ao sul do ponto de amostragem. Concomitante a esse sistema de drenagem nas proximidades, tem-se, a ação de tempestades, o que explica a alta concentração de minerais pesados se localizar no ambiente de pós-praia.

Praias de enseada como Santa Clara e Tatagiba apresentam granulometria mais fina, denotando ambiente de baixa energia de ondas. Tal constatação deve-se ao fato dessas praias se encontrarem relativamente abrigadas da ação dos processos litorâneos e do clima de ondas regional. A baixa energia desses ambientes pode explicar a baixa concentração de minerais pesados, constatada na praia de Santa Clara, uma vez que a energia das ondas não é capaz de realizar o transporte e deposição de uma grande quantidade de minerais pesados, além de não ser capaz de remover seletivamente os minerais leves de volta para o mar.

Em determinadas condições, o fluxo de água na desembocadura de um rio pode funcionar como um obstáculo que bloqueia o transporte dos sedimentos por deriva litorânea (Komar, 1973; Martin et al., 1997). Dessa forma, a praia de Barra de Itabapoana II parece ser controlada pela descarga do rio Itabapoana e pela corrente de deriva litorânea de norte para sul, abrigando a praia e consequentemente favorecendo a deposição de material fino.

$\mathrm{Na}$ praia de Ponta do Retiro, a ação constante de ondas sobre a base de falésias vivas da Formação Barreiras promove a erosão e remobilização de material para a ante-praia. Por sua vez, a corrente de deriva litorânea transporta os sedimentos para os outros pontos estudados, disseminando o conteúdo de minerais pesados proveniente da Formação Barreiras.

As assembleias discriminadas pela análise de agrupamento podem ser separadas em três localizações. A assembleia 1 corresponde às amostras do sul da área, próximo ao rio Paraíba do Sul, a assembleia 2 à porção central e a assembleia 3 à porção central e norte da área, próxima ao rio Itabapoana e à drenagem de Guaxindiba. A assembleia 1 reflete diretamente o conteúdo de minerais provenientes do rio Paraíba do Sul. A assembleia 2 pode ser considerada uma mistura das assembleias 1 e 3 e é fortemente influenciada pela Formação Barreiras, evidenciada pela abundância de limonita. A assembleia 3 é influenciada 
diretamente pelo rio Itabapoana e pela drenagem próxima à praia de Guaxindiba, que disseca a Formação Barreiras. A ocorrência de ondas de tempestade, de sul para norte, dispersa os sedimentos do rio Paraíba do Sul, que representa uma descarga de sedimentos de grande volume.

$\mathrm{O}$ arredondamento dos grãos de minerais pesados é predominantemente anguloso a subanguloso. Apesar de ser um mineral mecanicamente instável com tendência ao arredondamento, os grãos de apatita encontramse angulosos, euédricos e com terminações pontiagudas. Essas características evidenciam a imaturidade textural das areias e indicam pouca abrasão mecânica relacionada ao transporte. Dessa forma, sugere-se que o transporte dos grãos seja realizado a curtas distâncias. A monazita é o único mineral que se apresenta arredondado a subarredondado. As hipóteses para o arredondamento desse mineral são o transporte fluvial a longas distâncias, o retrabalhamento do grão por ondas e correntes e a proveniência de terrenos reciclados. Como a maturidade textural dos grãos revelou, o transporte ocorre a curtas distâncias e o retrabalhamento dos grãos por ondas e correntes se mostrou pouco influente. Dessa forma, a hipótese da proveniência de terrenos reciclados para os grãos de monazita se torna a mais aceitável. De acordo com estudos anteriores (Gonçalves, 2004; Santos et al.,
2005), o conteúdo de minerais pesados da Formação Barreiras foi originado da reconcentração de minerais erodidos do embasamento pré-cambriano enquanto os minerais instáveis foram eliminados por intemperismo químico. A assembleia de minerais pesados de amostras da Formação Barreiras da região caracteriza-se por uma alta maturidade mineralógica, com grande concentração de concreções limoníticas e ilmenita (Gonçalves, 2004). A monazita representa um dos poucos minerais que resistiram quimicamente à permanência na Formação Barreiras (Addad, 2001) e destaca-se com elevada concentração em Barra de Itabapoana, devido à contribuição dos granitóides desta área (Santos et al., 2005).

Nas assembleias mineralógicas ocorre o mineral espinélio disseminado nas amostras, apresentando diversas cores. De acordo com Deer et al. (1992), o espinélio ocorre em rochas metacarbonáticas e em granulitos. Levando em consideração a boa preservação em que os grãos se encontram e os aspectos granulométricos que revelaram o transporte a curtas distâncias, a fonte mais provável dos grãos de espinélio são os terrenos granulíticos, pois os terrenos metacarbonáticos se encontram interiorizados. Além disso, foi registrada, no trabalho de Rego (1989), a presença de espinélio como mineral acessório nas rochas charnockíticas da Unidade Bela Joana.

\section{CONCLUSÕES}

A granulometria das amostras varia de areia muito grossa à silte com predominância de areia média a muito fina. $O$ grau de selecionamento dos sedimentos é moderadamente selecionado na maioria das amostras estudadas. As declividades na face da praia variam entre $2^{\circ}$ (Fazenda Buena) a $12^{\circ}$ (Gargaú I e II). O estágio morfodinâmico das praias varia entre intermediário a dissipativo, denotando ambiente de baixa a média energia.

Os grãos apresentam-se, de modo geral, de subangulosos a angulosos e bem preservados, com exceção da monazita com padrão arredondado a subarredondado. Essa constatação aponta para transporte fluvial de curta distância. Como as praias da região são de baixa a média energia, a energia das ondas exerce pouca influência no retrabalhamento dos grãos, possibilitando que os sedimentos apresentem características estritamente fluviais.

O conteúdo de minerais pesados das praias estudadas é caracterizado pela presença de anfibólio, apatita, biotita, cianita, epidoto, espinélio, estaurolita, ilmenita, limonita, magnetita, monazita, muscovita, granada, piroxênio, rutilo, sillimanita, turmalina e zircão, com predomínio de ilmenita, limonita, anfibólio e apatita. As assembleias de minerais pesados foram discriminadas revelando predomínio de anfibóilio na assembleia 1, limonita na assembleia 2 e ilmenita na assembleia 3. De acordo com a distribuição dos minerais pesados nas praias, foi possível concluir que a dispersão dos sedimentos ocorre de norte para sul pela deriva litorânea com expressiva contribuição da descarga do rio Paraíba do Sul, que tem seus 
sedimentos depositados nas praias pela ação das ondas de tempestade de sul para norte.

Os terrenos metamórficos de alto grau podem representar as principais áreas-fonte dos sedimentos pela proximidade da área costeira. Essa hipótese é corroborada pela presença do mineral espinélio nas amostras. A Formação Barreiras constitui uma fonte secundária de sedimentos para as praias, sendo dissecada pela drenagem próxima à Guaxindiba e pelo rio Itabapoana. Além disso, a falésia viva localizada na praia de Ponta do Retiro é erodida diretamente pela ação das ondas, contribuindo para a dispersão dos sedimentos provenientes da Formação Barreiras para as outras praias estudadas.

\section{AGRADECIMENTOS}

Os autores agradecem à Coordenação de Aperfeiçoamento de Pessoal de Nível Superior CAPES pela concessão da bolsa de mestrado; ao Laboratório de Geologia Costeira, Sedimentologia e Meio Ambiente - LAGECOST do Departamento de Geologia e Paleontologia do Museu Nacional / UFRJ; e ao Laboratório de Petrografia e Mineralogia do Departamento de Geologia e Paleontologia do Museu Nacional / UFRJ.

\section{REFERÊNCIAS}

ADDAD, J. E. Minerais pesados - Uma ferramenta para prospecção, proveniência, paleogeografia e análise ambiental. São Paulo: edição independente, 67 p, 2001.

ALMEIDA, F.F. M.; HASUI, Y.; BRITO-NEVES, B. B \& FUCK R. A. Brazilian Structural Provinces: an introduction. Earth Science Review, SpecialIssue,v. 17, p. $1-29,1981$.

CASCALHO, J.; TABORDA, R.; RODRIGUES, A.; OLIVEIRA, A.; POMBO, J.; FRADIQUE, C. \& BALSINHA, M. 2006. Os Minerais pesados como indicadores dos processos sedimentares - alguns exemplos da plataforma continental portuguesas. In: VII CONGRESSO NACIONAL DE GEOLOGIA, 7, 2006, Évora. Resumos expandidos... Sociedade Geológica de Portugal, 2006, p.1-4.

CASTRO, J. W. A.; SENRA, M. C. E. \& RAMOS, R. R. C. Coquinas da paleolaguna da Reserva Tauá - Pântano da Malhada, Cabo Frio, RJ, In: WINGE, M.; SCHOBBENHAUS, C.; SOUZA, C. R. G.; BERBETBORN, M.; QUEIROZ, E. T. \& CAMPOS, D. A. (Coordenadores). Sítios Geológicos e Paleontológicos do Brasil vol.II. Brasília: SIGEP, p. 269-276, 2009.

CASTRO, J. W. A.; SUGUIO, K.; SEOANE, J. C. S.; CUNHA, A. M. \& DIAS, F. F. Sea-level fluctuations and coastal evolution in the state of Rio de Janeiro, southeastern Brazil. Annals of the Brazilian Academy of Sciences, v. 86, n.2, p. 671-683. 2014.

DEER, W. A.; HOWIE, R. A. \& ZUSSMAN, J. An Introduction to the Rock-Forming Minerals. London: Pearson United Kingdom, 712 p., 1992.

FRIEDMAN, G. M. Distinction between dune, beach and river sands from their textural characteristics. Journal of Sedimentary Petrology, v. 31, n. 4, p. 514-529, 1961.

GONÇALVES, C. Z. 2004. Proveniência e distribuição dos minerais pesados no complexo deltaico do rio Paraíba do Sul. Niterói, 2004. 198 p. Dissertação (Mestrado em Geologia) - Instituto de Geologia, Universidade Federal Fluminense.

HEILBRON, M.; PEDROSA-SOARES, A. C.; CAMPOSNETO, M. C.; SILVA, L. C.; TROUW, R. A. J.; JANASI, V. A. Província Mantiqueira. In: MANTESSO-NETO, V.; BARTORELLI, A.; CARNEIRO, C. D. R.; BRITO NEVES, B. B. (Coordenadores). Geologia do Continente Sul-Americano - Evolução da Obra de Fernando Flávio Marques de Almeida. Beca, p. 203-234, 2004.

HEILBRON, M.; VALERIANO, C. M; TASSINARI, C. C. G.; ALMEIDA, J.; TUPINAMBÁ, M.; SIGA, JR., O.;
TROUW, R. Correlation of Neoproterozoic terranes between the Ribeira Belt, SE Brazil and its African counterpart: comparative tectonic evolution and open questions. Geological Society, London, Special Publications, p. 211-237, 2008.

KOMAR, P. D. Computer models of delta growth due to sediment input from rivers and longshore transport. Geological Society America Bulletin, v. 84, p. 2217-2226, 1973.

KOMAR, P. D. The entrainment, transport and sorting of heavy minerals by waves and currents. In: MANGE, M. A. \& WRIGHT, D. T. (Coordenadores), Heavy Minerals in Use. Oxford: Elsevier, p. 3-48, 2007.

MANGE, M. A. \& MAURER, H. F. W. Heavy Minerals in Colour. London: Chapman \& Hall, 147 p. 1992.

MANGE, M. A. \& WRIGHT, D. T. High-resolution Heavy Mineral Analysis (HRHMA): A Brief Summary. In: MANGE, M. A. \& WRIGHT, D. T. (Coordenadores), Heavy Minerals in Use. Oxford: Elsevier, p. 433-436, 2007.

MARTIN, L; SUGUIO, K; DOMINGUEZ, J. M. Geologia do quaternário costeiro do litoral norte do Rio de Janeiro e do Espírito Santo. Belo Horizonte: CPRM Serviço Geológico do Brasil, 104 p, 1997.

MORAIS, R. M. O. 2007. Sistemas fluviais terciários na área emersa na bacia do Espírito Santo (Formações Rio Doce e Barreiras). Rio de Janeiro, 2007. 144 p. Tese (Doutorado em Geologia) - Instituto de Geologia, Universidade Federal do Rio de Janeiro.

MORAIS, R. M. O.; MELLO, C. L.; COSTA, F. O. \& SANTOS, P. F. Fácies Sedimentares e Ambientes Deposicionais Associados aos Depósitos da Formação Barreiras no Estado do Rio de Janeiro. Revista do Instituto de Geociências - USP, v. 6, n. 2, p.19-30, 2006.

MORTON, A. C. \& HALLSWORTH, C. Identifying provenance-specific features of detrital heavy mineral assemblages in sandstones. Sedimentary Geology, v. 90, p. 241-256, 1994.

MORTON, A. C. \& HALLSWORTH, C. Processes controlling the composition of heavy mineral assemblages in sandstones. Sedimentary Geology, v. 124, p. 3-29, 1999.

PARKS, J. M. Cluster analysis applied to multivariate geologic problems. Journal of Geology, v.74, p. 703715. 1966.

PEREIRA, R. M; ÁVILA, C. A.; LIMA, P. R. A. S. Minerais em grãos: técnicas de coleta, preparação e identificação. São Paulo: Oficina de Textos, 128 p, 2005. 
PINHO, U. F. 2003. Caracterização do estado do mar na Bacia de Campos. Rio de Janeiro, 2003. 145 p. Dissertação (Mestrado em Engenharia Oceânica) - Instituto Alberto Luiz Coimbra de Pós-graduação e Pesquisa em Engenharia, Universidade Federal do Rio de Janeiro.

REGO, I. T. S. F. 1989. Petrologia e Geoquímica da Unidade Charnockítica Bela Joana, Região de São Fidélis - RJ. Rio de Janeiro, 1989. 348 p. Tese (Doutorado em Geoquímica e Geotectônica) - Instituto de Geociências, Universidade de São Paulo.

RICCOMINI, C.; SANT'ANNA, L. G. \& FERRARI, A. L. Evolução geológica do rift continental do Sudeste do Brasil. In: MANTESSO-NETO, V.; BARTORELLI, A.; CARNEIRO, C. D. R. \& BRITO-NEVES, B. B. (Coordenadores). Geologia do continente Sul-Americano: evolução da obra de Fernando Flávio Marques de Almeida. São Paulo: Beca, p. 383-405, 2004.

ROSENTAL, S. Terras Raras In: CETEM, Rochas e Minerais Industriais: Usos e especificações - Parte 2. Rio de Janeiro, p. 817-840, 2008

SANTOS, P. F.; COSTA, F. O.; MELLO, C. L. \& MORAIS, R. M. O. 2005. Relação entre a distribuição de minerais pesados em sedimentos litorâneos e da Formação Barreiras, no litoral do Estado do Rio de Janeiro. In: CONGRESSO BRASILEIRO DE ESTUDOS DO QUATERNÁRIO, 10, 2005. Resumos expandidos... São Paulo: Associação Brasileira de Estudos do Quaternário, 2005, p. 1-5.

SCHMITT, R. S.; TROW, R. A. J.; VAN SCHMUS, W. R. \& PIMENTEL, M. M. Late amalgamation in the central part of West Gongwana: new geochronological data and the characterization of a Cambrian collisional orogeny in the Ribeira Belt (SE Brazil). Precambrian Research, v. 133, p. 29-61, 2004.
SILVA, C. G. 2001. Pláceres Marinhos. Revista Brasileira de Geofísica, v. 18, n. 3, p.327-336, 2001.

SILVA, L C. \& CUNHA, H. C. S (Coordenadores). Geologia do Estado do Rio de Janeiro: texto explicativo do mapa geológico do Estado do Rio de Janeiro. Brasília: CPRM, 24 p., 2001.

SUGUIO, K. Introdução à Sedimentologia. São Paulo: Edgard Blucher, 317p, 1973.

THOMAZ FILHO, A. \& RODRIGUES, A. L. O alinhamento de rochas alcalinas Poços de Caldas-Cabo Frio (RJ) e sua continuidade na cadeia Vitória-Trindade. Revista Brasileira de Geociências, v. 29, n. 2, p.189-194, 1999.

TUPINAMBÁ, M; HEILBRON, M.; DUARTE, B. P.; NOGUEIRA, J. R.; VALLADARES, C.; ALMEIDA, J.; SILVA, L. G. E.; MEDEIROS, S. R.; ALMEIDA, C. G.; MIRANDA, A.; RAGATKY, C. D.; MENDES, J. \& LUDKA, I. Geologia da Faixa Ribeira Setentrional: Estado da Arte e Conexões com a Faixa Araçuaí. Geonomus, v. 15, n.1, p. 67-79, 2007.

UNITED STATES ARMY CORPS OF ENGINEERS USACE. Coastal Geology. Washington: Department of the Army, 393 p, 1995.

Manuscrito recebido em 25 de abril de 2016 Revisado e aceito em 19 de junho de 2016 